\title{
Retinoblastoma Clinical TNM Finding v8
}

National Cancer Institute

\section{Source}

National Cancer Institute. Retinoblastoma Clinical TNM Finding v8. NCI Thesaurus. Code C140676.

A clinical finding about one or more characteristics of retinoblastoma, following the rules of the TNM AJCC v8 classification system. 